\title{
Article \\ Using Biochar and Vermiwash to Improve Biological Activities of Soil
}

\author{
Michelangelo Becagli, Iduna Arduini * (i) and Roberto Cardelli
}

Citation: Becagli, M.; Arduini, I.; Cardelli, R. Using Biochar and

Vermiwash to Improve Biological

Activities of Soil. Agriculture 2022, 12,

178. https://doi.org/10.3390/

agriculture12020178

Academic Editor: Gederts Ievinsh

Received: 3 January 2022

Accepted: 25 January 2022

Published: 26 January 2022

Publisher's Note: MDPI stays neutral with regard to jurisdictional claims in published maps and institutional affiliations.

Copyright: () 2022 by the authors. Licensee MDPI, Basel, Switzerland. This article is an open access article distributed under the terms and conditions of the Creative Commons Attribution (CC BY) license (https:// creativecommons.org/licenses/by/ $4.0 /)$.

\author{
Department of Agriculture, Food and Environment, University of Pisa, 56124 Pisa, Italy; \\ michelangelo.becagli@phd.unipi.it (M.B.); roberto.cardelli@unipi.it (R.C.) \\ * Correspondence: iduna.arduini@unipi.it; Tel.: +39-050-2218902
}

\begin{abstract}
The recycling of key nutrients and bioenergy from waste materials is a goal of sustainable agriculture. The co-application of biochar and a vermicompost solution (vermiwash) could enhance the positive effects of both materials on soil biomass and biological activities. Tomato plants were grown in soil amended with biochar, mixed at a rate of $2 \% w / w$, and vermiwash, applied through fertigation at a rate of $25 \mathrm{mg}$ per plant, alone (B and V) and in combination (BV). Organic C, dissolved organic C (DOC), soil biomass $C$, and some enzymatic activities were determined at the start (T0) and the end (T100) of the cultivation period in bulk soil and rhizosphere soil. B and V significantly increased the organic $C$ and soil biomass contents. In addition, B retained the DOC species derived from the soil and, in the BV treatment, also the humic substance of the vermiwash. Generally, all the parameters achieved higher values in the rhizosphere than in the bulk soil. The altered soil index three (AI3) of enzyme activities suggests that applying V and B is helpful for the soil microorganisms. Synergisms between B and V were low in the bulk soil and clearly evident in the rhizosphere.
\end{abstract}

Keywords: biochar; $\beta$-glucosidase; organic fertilisers; phosphatase; soil enzyme activity; soil microbiome; Solanum lycopersicum; urease; vermicompost

\section{Introduction}

Biochar is a pyrolysis product derived from the thermal decomposition in the absence of oxygen of various organic, primarily woody, sources. It has an aromatic structure, is rich in carbon, and has stable physical and chemical properties. Biochar improves the productivity of cultivated plants not only because of its nutrient content but also through better nutrient retention, increase in soil cation exchange capacity, and an improvement in the physical properties of the soil, including an increase in water retention [1].

Many studies indicate that biochar can increase the biomass of soil microorganisms and stimulate their enzymatic activity [2]. However, the addition of biochar to soil has also led to conflicting data on the activity of given enzymes [3]. The biochar introduced into the soil creates a favourable habitat for microorganisms, especially in terms of higher soil porosity. Soil enzymes catalyse the biodegradation phases of different substrates, thus favouring their decomposition. The complex factors influencing soil biology are very wide, and therefore evaluating the enzymatic activities is a necessary step towards a complete understanding of the key processes that connect populations of microorganisms and trace element dynamics, following the application of biochar to soils [4].

Biochar can be enriched with organic and/or mineral nutrients to mitigate its possible negative effects and the addition of compost was found to increase the organic $\mathrm{C}$ of the soil and influence the enzyme activity [5,6]. Vermicomposts are generally more stable than composts, have greater availability of mineral nutrients, and better biological properties [7]. Tejada and González [8] demonstrated that vermicompost improved both soil biomass and the activity of selected soil enzymes, which increased the yield and quality of rice crops. Earthworms play a fundamental role in vermicomposting together with microbes in the 
conversion of solid organic waste into a soil conditioner that is rich in nutrients. During the production of vermicompost, various products are created such as vermicompost tea, vermi-liquid (liquid collected during the worming process), and earthworm biomass. The leachate (vermiwash) is generated together with the vermicomposting process, commonly referred to as vermicomposting leachate or worm-bed leachate [9]. This product contains soluble nutrients in addition to various organic acids and mucus from earthworms and microbes [10]. The novelty of this work is the co-application of vermiwash and biochar to soil, hypothesising that activating biochar with vermiwash will improve the biological activity in the soil. By recovering and recycling key nutrients and bioenergy from waste materials, this approach reduces the use of inorganic fertilisers and, thus, meets the objectives of sustainable agriculture which are the subject of the Farm to Fork strategy of the European Union. Moreover, it applies agroecological farming methods that are growing in global interest as attractive and safer alternatives to the use of imported fertilisers and chemicals for food production [11].

This study aimed to evaluate the impact of vermiwash, biochar, and their combination on the organic substance and biological activities of a soil used for tomato cultivation in greenhouse conditions. The study proved that both materials increased soil fertility and stimulated rhizosphere activity.

\section{Materials and Methods}

\subsection{Experiment Setup}

A randomised experiment consisting of four treatments with five replicates was conducted in a greenhouse at the Department of Agriculture, Food and Environment of the University of Pisa. Treatments consisted of a control soil without amendments (CTR), soil amended once a week with vermiwash (V), soil amended with biochar obtained by pyrogasification (B), and soil amended with the same biochar treatment and periodically treated as for $\mathrm{V}(\mathrm{BV})$.

\subsection{Materials}

Agricultural soil was collected at a depth between 0 and $15 \mathrm{~cm}$ from a field at the agricultural research centre "Enrico Avanzi" of the University of Pisa (Lat. 4339'38.96" N; Long. $10^{\circ} 18^{\prime} 22.17^{\prime \prime} \mathrm{E} ; 1 \mathrm{~m}$ above sea level) and, after being air dried, it was sieved through a $2 \mathrm{~mm}$ mesh to remove large fragments. The soil was classified as sandy, Typic Xerorthent. The main soil properties were determined following standard methods [12]: 86.3\% sand, $7.9 \%$ silt, 5.8\% clay, $48 \%$ water holding capacity (WHC), $8.2 \mathrm{pH}, 5.8 \% \mathrm{CaCO}_{3}, 0.91 \%$ organic C, $0.15 \mathrm{~g} \mathrm{~kg}^{-1}$ DOC, $1.01 \mathrm{~g} \mathrm{~kg}^{-1}$ total $\mathrm{N}, 10.4 \mathrm{mg} / \mathrm{kg}$ available $p, 78.6 \mathrm{mg} / \mathrm{kg}$ exchangeable $\mathrm{K}$, and $4.93 \mathrm{cmol}^{(+)} / \mathrm{kg}$ cation exchange capacity.

Biochar was produced from woodchips (30-50 g) of pristine forests (Abies sp., Fagus sp., Robinia pseudoacacia) by pyrogasification with a co-current fixed bed ("downdraft") "syngaSmart ${ }^{\circledR \prime \prime}$ gasifier (RESET s.r.l. https:/ / www.reset-energy.com/; accessed on 24 January 2022). The average heating rate before reaching a peak of $800{ }^{\circ} \mathrm{C}$ was $15^{\circ} \mathrm{C}$ to $18^{\circ} \mathrm{C} / \mathrm{min}$. The characterisation of biochar followed the official methods approved by Italian regulations (D.lgs. 75/2015), as reported in Table 1. Following the Guidelines for Certification of the International Biochar Initiative (IBI, http: / / www.european-biochar.org / en/ebc-ibi; accessed on 24 January 2022), the total organic carbon content was classified as Class 1 . The biochar was applied to soil at a rate of $2 \% w / w$, which corresponded to $34 \mathrm{t} / \mathrm{ha}$ in dry weight, and the physical and chemical parameters of the mixture were analysed (Table 2). 
Table 1. Selected characteristics of the biochar used.

\begin{tabular}{ccc}
\hline Parameter & U.m. & Biochar \\
\hline Water Holding Capacity & $\%$ & 400 \\
pH & & 11.3 \\
Total C & $\%$ & 68.5 \\
Organic C & $\%$ & 68.4 \\
Total N & $\mathrm{g} / \mathrm{kg}$ & 0.516 \\
C:N ratio & & 132.7 \\
Total P & $\mathrm{mg} / \mathrm{kg}$ & 340 \\
Total K & $\mathrm{mg} / \mathrm{kg}$ & 4.3 \\
\hline
\end{tabular}

Table 2. Soil characteristics after amendment with biochar.

\begin{tabular}{ccc}
\hline Parameter & U.m. & Soil and Biochar $(\mathbf{2} \%$ w/w) \\
\hline Water Holding Capacity & $\%$ & 52 \\
pH & & 8.4 \\
Organic C & $\%$ & 3.4 \\
Cation Exchange Capacity & $\mathrm{cmol}^{(+)} / \mathrm{kg}$ & 9.54 \\
Total N & $\mathrm{g} / \mathrm{kg}$ & 1.02 \\
Available $p$ & $\mathrm{mg} / \mathrm{kg}$ & 17.2 \\
Exchangeable K & $\mathrm{mg} / \mathrm{kg}$ & 164.6 \\
Water Holding Capacity & $\%$ & 52 \\
\hline
\end{tabular}

The vermicompost used in this experiment was obtained from mature pig manure derived from organic livestock. The initial biomass was converted into vermicompost in an open-air litter with the earthworm species Eisenia fetida and Eisenia andrei. The $\mathrm{C} / \mathrm{N}$ ratio of the mature vermicompost was 14 , and the concentration in heavy metals was undetectable or below the limits set by the Italian regulation. After four months, the vermiwash was produced in a laboratory-scale plant through cold extraction, which means that a surplus of cold water was applied to vermicompost, and the leachates were collected. The chemical properties of vermiwash were: $60 \%$ organic matter, $80 \%$ total humic substances (in organic matter content), $\mathrm{pH} 8.00,2 \%$ total nitrogen content, $1.5 \%$ total organic nitrogen, and $20 \mathrm{C} / \mathrm{N}$ ratio. The microbial characterisation is reported in Table 3. Vermiwash was applied weekly through fertigation at a rate of $25 \mathrm{mg}$ per pot [13], corresponding to $300 \mathrm{~g}$ on $1000 \mathrm{~m}^{2}$.

Table 3. Microbiological composition of vermiwash. CFU, colony forming unit; MPN, most probable number.

\begin{tabular}{ccc}
\hline Functional Diversity Group & U.m. & Composition \\
\hline Amylolytic & $\mathrm{CFU} / \mathrm{mL}$ & $2.2 \times 10^{3}$ \\
Cellulolytic & $\mathrm{CFU} / \mathrm{mL}$ & $1.4 \times 10^{4}$ \\
Nitrosant & $\mathrm{MPN} / \mathrm{mL}$ & $2 \times 10^{2}$ \\
Nitricant & $\mathrm{MPN} / \mathrm{mL}$ & $4.5 \times 10^{3}$ \\
Sulphate reducers & $\mathrm{MPN} / \mathrm{mL}$ & $4.5 \times 10^{2}$ \\
Sulphur oxidants & $\mathrm{MPN} / \mathrm{mL}$ & $2.5 \times 10^{1}$ \\
Aerobic nitrogen-fixing & $\mathrm{MPN} / \mathrm{mL}$ & $2.5 \times 10^{3}$ \\
Anaerobic nitrogen-fixing & $\mathrm{MPN} / \mathrm{mL}$ & $2 \times 10^{3}$ \\
\hline
\end{tabular}

\subsection{Experiment Management}

The mixture of soil and biochar for B and BV treatments was prepared one week before filling the pots, and vermiwash solution was added in $\mathrm{V}$ and $\mathrm{BV}$ and all pots were wetted at $60 \%$ WHC to enable the biochar to be colonised by the microorganisms of soil and V. Tomato plants (Solanum lycopersicum L.) obtained from a commercial nursery were individually transplanted at the 3-leaf stage (30 DAS) into $18 \mathrm{~L}$ plastic pots containing $16 \mathrm{~kg}$ of soil. 
To ensure an adequate nitrogen, phosphorus, and potassium nutrition for the plants, a basal dressing was prepared for each pot with potassium nitrate and calcium nitrate (60 N kg/ha), monopotassium phosphate (30 $\left.\mathrm{P}_{2} \mathrm{O}_{5} \mathrm{~kg} / \mathrm{ha}\right)$ and potassium sulphate $\left(120 \mathrm{~K}_{2} \mathrm{O} \mathrm{kg} / \mathrm{ha}\right)$. The remaining nutritional requirements of the recommended doses for tomato $\left(180 \mathrm{~N} \mathrm{~kg} / \mathrm{ha} ; 30 \mathrm{P}_{2} \mathrm{O}_{5} \mathrm{~kg} / \mathrm{ha} ; 120 \mathrm{~K}_{2} \mathrm{O} \mathrm{kg} / \mathrm{ha}\right.$ ) were provided through fertigation once a week.

\subsection{Chemical Analyses}

Soil samples were collected at seedling planting (T0) and after 100 days, corresponding to the stage of fruit ripening. At T100, rhizosphere (Rz) and bulk (Bk) soil fractions were obtained following the method described in Barillot et al. [14].

Total organic carbon (TOC) was determined by dry combustion (induction furnace 900 CS, Eltra), after the removal of carbonate C. Dissolved organic carbon (DOC) was determined with an organic $C$ analyser for liquid samples (Hach QbD1200) after stirring soil samples with distilled water (soil/ $\mathrm{H}_{2} \mathrm{O}$ 1:20) at room temperature for $24 \mathrm{~h}$, centrifuging the suspension at 10,000 rpm for $10 \mathrm{~min}$ and, then, filtering it through a $0.45 \mathrm{~mm}$ glass fibre. The soil microbial biomass C (MBC) was determined following the method of Vance et al. [15], which consisted of the extraction of organic $C$ from fumigated and unfumigated soils with a $1 \mathrm{~N} \mathrm{~K}_{2} \mathrm{SO}_{4}$ solution. The obtained organic $\mathrm{C}$ was measured with a QBD1200 Laboratory TOC Analyser (Hach Company, Loveland, CO, USA). To convert into microbial biomass C the difference in soluble $C$ between the fumigated and unfumigated soils, an extraction efficiency coefficient $(\mathrm{Kc})$ equal to 0.45 was used.

The enzymatic analyses were performed as described by Cardelli et al. [16]. Dehydrogenase activity $(\mathrm{DH})$ was estimated with the colorimetric assay of the 2,3,5-triphenylformazan (TPF) obtained by the microorganism from the reduction of 2,3,5-triphenyltetrazolium chloride (TTC). To estimate the $\beta$-glucosidase activity (GL), soil samples were incubated at $37{ }^{\circ} \mathrm{C}$ for $60 \mathrm{~min}$ and the reaction product $\mathrm{p}$-nitrophenol obtained from the substrate 4-nitrophenyl-ß-D-glucopiranosyde was determined colorimetrically, at $410 \mathrm{~nm}$. To determine the alkaline phosphatase activity (AP), p-nitrophenyl phosphate was added to the soil samples and the p-nitrophenol released by hydrolysis was measured colorimetrically. To estimate the arylsulphatase activity (AS), soil samples were incubated at $37^{\circ} \mathrm{C}$ for $1 \mathrm{~h}$ with the substrate $\mathrm{p}$-nitrophenyl sulphate. The $\mathrm{p}$-nitrophenol produced by the microorganisms was extracted by dilute alkali $\left(\mathrm{CaCl}_{2} 0.5 \mathrm{M}\right.$ and $\left.\mathrm{NaOH} 0.5 \mathrm{M}\right)$ and determined at $400 \mathrm{~nm}$ with a colorimetric method. Urease activity (UR) was assessed by a spectrophotometric method measuring the ammonia released from urea after a $2 \mathrm{~h}$ incubation of soil samples with urea at $37^{\circ} \mathrm{C}$.

The alteration index (AI3) combines the activity of three enzymes to estimate the degree of soil quality alteration in response to treatments. Following Puglisi et al. [17], AI3 was calculated as:

$$
\mathrm{AI} 3=(7.87 \times \beta \text {-glucosidase })-(8.22 \times \text { phosphatase })-(0.49 \times \text { urease })
$$

where the activities of enzymes were expressed in micromoles of p-nitrophenol per gram of soil per hour (for $\beta$-glucosidase and phosphatase), and in micrograms of urea per gram of soil per hour (urease).

\subsection{Statistical Analysis}

ANOVA was used to analyse the effects of the treatment sample time (T0 and T100), fertiliser (CTR, V, B, BV), soil region (Bk, Rz), and their interactions, with data arranged in a split-split plot design with five replicates, each consisting of one pot for one tomato plant. The JMP software (SAS Institute, Inc., Cary, NC, USA) was used, and the Tukey-Kramer post-hoc test was used to separate significantly different means using $p<0.05$. 


\section{Results and Discussion}

\subsection{Total and Dissolved Organic C}

As expected, the addition of vermiwash and especially biochar to the soil increased the total organic carbon (TOC) content at T0 (Figure 1). In all treatments, tomato cultivation did not significantly affect TOC in the bulk soil, while rhizosphere soil values were approximately $40 \%$ higher in the presence of B. However, in the Bk soil at T100,88\% of the initial TOC was found in the control, whereas $92 \%$ and $94 \%$ were found in V and BV, respectively, and only $80 \%$ in $\mathrm{B}$, thus indicating a faster mineralisation of the soil organic matter. These findings agree with Awad et al. [18], who found that the decomposition of plant residues in soil was enhanced by biochar, probably because the higher soil aeration and porosity induced by biochar favoured microbial growth and respiration [19]. A further explanation could be a positive priming effect [20]. The \% of organic $C$ was significantly higher in the rhizosphere soil than in bulk soil in all the treatments, to which probably contributed root exudates in the form of easily decomposable polysaccharides (O/N-alkyl C) [21].
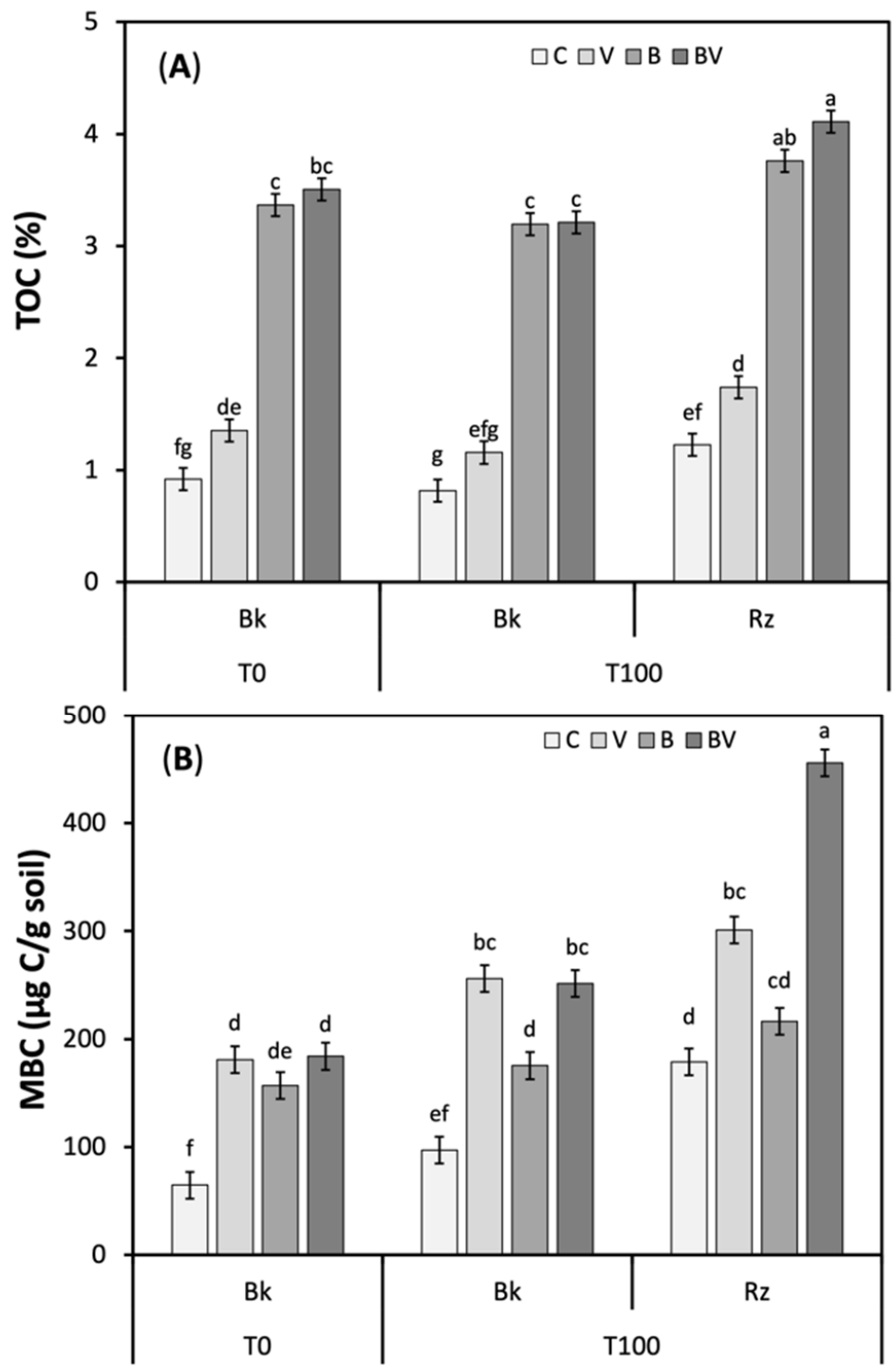

Figure 1. Total organic $C(A)$ and dissolved organic $C(B)$ in the bulk (Bk) and rhizosphere (Rz) soils amended with different fertilisers at the start (T0) and end (T100) of tomato cultivation. CTRcontrol; V-vermiwash; B-biochar; BV-biochar together with vermiwash. Bars represent SE of the interaction sample time $\times$ fertiliser $\times$ soil region. Different letters indicate significant differences among treatments $(p<0.05$; Tukey's test). 
At T0, the dissolved organic carbon (DOC) was highest in the soil treated with vermiwash and lowest when containing biochar, demonstrating that the labile organic matter of $\mathrm{V}$ was promptly stabilised by biochar, as reported by Schulz and Glaser [22] for compost (Figure 1). After 100 days in the Bk soil, the DOC decreased in CTR and V, and increased in $\mathrm{B}$ and especially in BV. The decrease with time in CTR and V could be due in part to the leaching caused by irrigation, and in part to the faster degradation of water-soluble $C$ that is in the first stage of mineralisation [23]. Biochar characteristics, such as high or low pyrolysis temperature, typologies (herbaceous, woody, or animal-derived by-products), biochar/soil ratio, and soil characteristics (texture, $\mathrm{pH}, \mathrm{CEC}$, nutrient content) may affect the impact of biochar on DOC [24]. In the Bk soil, biochar retained the humified DOC species derived from the soil, but also the humic substance present in the vermiwash of the BV treatment, thus proving to be an essential instrument for preserving the soil organic matter (Figure 1). Our results could be explained by the selective behaviour of the pyroligneous carbon of biochar in retaining humic substances compared to labile organic compounds $[25,26]$. In the Rz soil, trends of DOC were similar as in the bulk soil in response to fertiliser, but in CTR and $\mathrm{V}$, the decrease over time was lower than in the Bk soil, whereas in B and especially BV, the increase was more pronounced, so that DOC values were significantly higher for all treatments (Figure 1). These patterns suggest that root exudates contributed to increase DOC in the Rz soil and that the release was stimulated by vermiwash.

\subsection{Soil Biomass}

The incorporation of fertilisers in the soil increased the microbial biomass $\mathrm{C}$ (MBC) from $65 \mu \mathrm{g} / \mathrm{g}$ in CTR, to $157 \mu \mathrm{g} / \mathrm{g}$ in B, and to approximately $183 \mu \mathrm{g} / \mathrm{g}$ in V and BV (Figure 2), which was due to the stimulation of soil microbiota in response to the easily available $C$ and/or to the addition of foreign microorganisms with the materials $[26,27]$.

Higher MBC was found in vermiwash compared to compost [28], and Uz et al. [29] also reported a strong increase in bacterial number when $\mathrm{V}$ was added to an alkaline soil. The MBC tended to increase over time in all treatments, but the increments were significant for all soil regions in $\mathrm{V}$ and $\mathrm{BV}$, only for the Rz soil in the control, and never for B, probably because the addition of biochar only moderately increased soil DOC, which is the most available substrate for microbial growth [30]. In the Bk soil, the high MBC recorded at T100 in the V and BV treatments was largely due to the weekly soil fertilisation, which undoubtedly stimulated microbial proliferation. At T100, the MBC of the BV treatments were approximately $80 \%$ higher in the $\mathrm{Rz}$ than in the Bk soil, while the increments were by only $20 \%$ in V and B, thus demonstrating a strong interaction of the two fertilisers in the rhizosphere, which affected positively tomato growth [31]. Gopal et al. [32] hypothesised that coconut leaf vermiwash, a wash of composting substrates and earthworm bodies, led to increased microbial populations by promoting soil nutrient content, and acted as a liquid fertiliser immediately and quickly absorbed by the roots of plants; in addition, the vermiwash by itself showed a very low microbial population, and on application to soil, the soil microbial population increased. In the $\mathrm{Rz}$ soil, the MBC of CTR reached similar values to $B$, revealing a key role of root exudates in stimulating microbial growth in unfertilised soils. The expression of microbial $\mathrm{C}$ as a percentage of organic $\mathrm{C}$ highlighted that vermiwash alone greatly stimulated the microbial biomass, with the highest values recorded in the Bk soil at T100 (Figure 2). The patterns of MBC \% observed in the Rz suggest a higher rhizodeposition of C compounds in both CTR- and vermiwash-amended soils. 

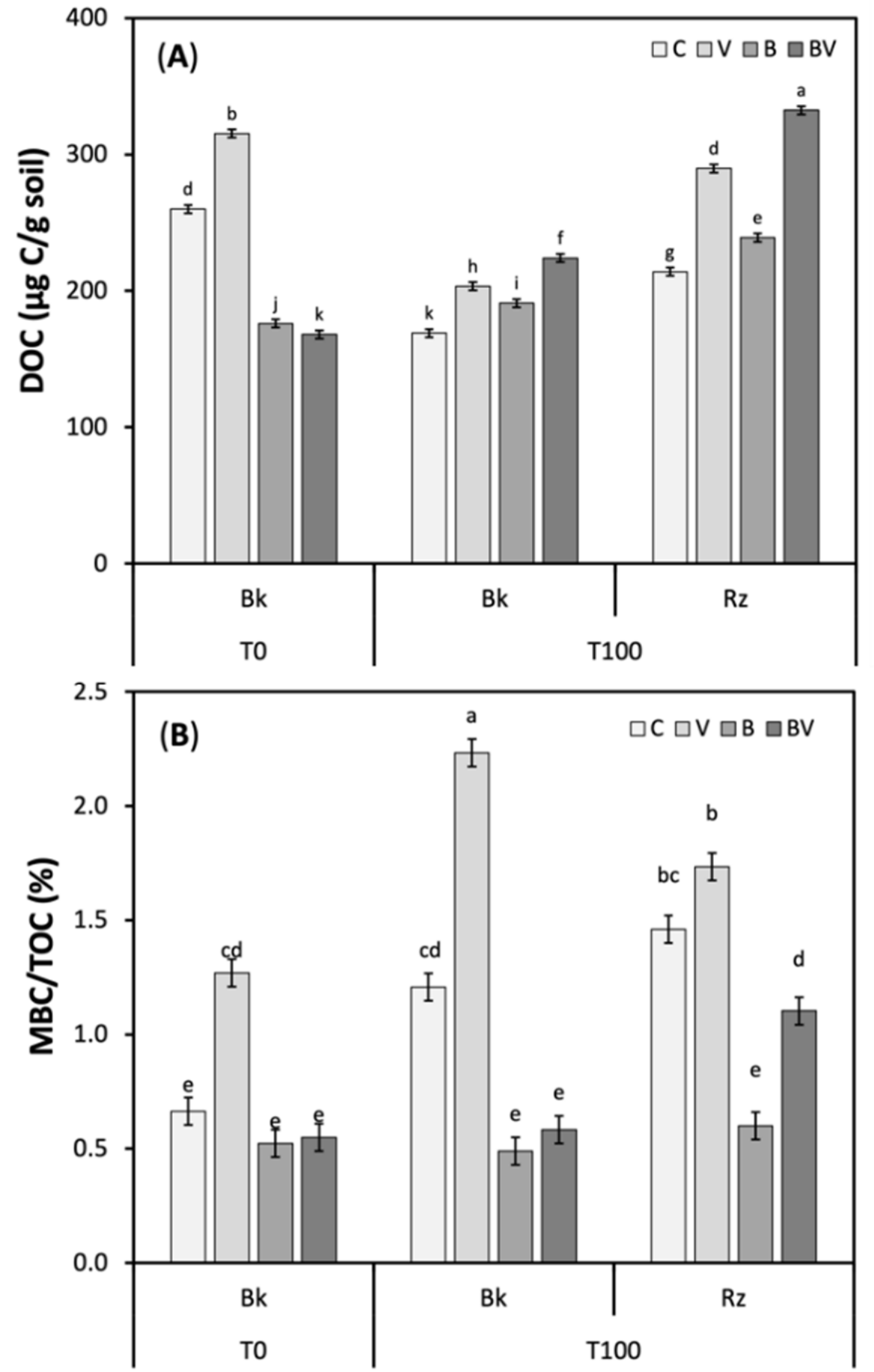

Figure 2. Microbial biomass $C(\mathbf{A})$ and $M B C$ percentage of total organic $C(\mathbf{B})$ in the bulk (Bk) and rhizosphere (Rz) soils amended with different fertilisers at the start (T0) and end (T100) of tomato cultivation. CTR - control; V-vermiwash; B-biochar; BV—biochar together with vermiwash. Bars represent SE of the interaction sample time $\times$ fertiliser $\times$ soil region. Different letters indicate significant differences among treatments ( $p<0.05$; Tukey's test).

\subsection{Soil Enzymatic Activities}

The addition of biochar and vermiwash to soil stimulated all the enzymatic activities tested in this study and, in general, activities increased after tomato cultivation and tended to be higher in the rhizosphere than the bulk soil (Table 4). 
Table 4. Enzyme activities of bulk and rhizosphere soils amended with different fertilisers at the start (T0) and end (T100) of tomato cultivation. V-vermiwash; B-biochar; BV—biochar together with vermiwash.

\begin{tabular}{|c|c|c|c|}
\hline \multirow[b]{2}{*}{ Fertiliser } & \multirow{2}{*}{$\begin{array}{c}\text { T0 } \\
\text { Bulk }\end{array}$} & \multicolumn{2}{|c|}{ T100 } \\
\hline & & Bulk & Rhizosphere \\
\hline & \multicolumn{3}{|c|}{ Dehydrogenase ( $\mu \mathrm{g}$ TTF/g.h) } \\
\hline CTR & $0.22 \pm 0.007^{c, d}$ & $0.38 \pm 0.012^{\mathrm{c}, \mathrm{d}}$ & $1.10 \pm 0.040^{\mathrm{a}, \mathrm{b}}$ \\
\hline $\mathrm{V}$ & $0.19 \pm 0.005^{\mathrm{c}, \mathrm{d}}$ & $0.75 \pm 0.034^{b, c}$ & $1.63 \pm 0.060^{\mathrm{a}}$ \\
\hline B & $0.20 \pm 0.004^{\mathrm{c}, \mathrm{d}}$ & $0.52 \pm 0.019^{\mathrm{c}, \mathrm{d}}$ & $1.62 \pm 0.050^{\mathrm{a}}$ \\
\hline \multirow[t]{2}{*}{ BV } & $0.12 \pm 0.005^{\mathrm{d}}$ & $0.46 \pm 0.021^{\mathrm{c}, \mathrm{d}}$ & $1.61 \pm 0.050^{\mathrm{a}}$ \\
\hline & \multicolumn{3}{|c|}{ Phosphatase ( $\mu \mathrm{g}$ p-nitrophenol/g.h) } \\
\hline CTR & $76.6 \pm 2.80^{\mathrm{h}}$ & $118.9 \pm 2.50^{\mathrm{f}, \mathrm{g}}$ & $172.6 \pm 3.44^{c}$ \\
\hline $\mathrm{V}$ & $144.2 \pm 3.60^{\mathrm{d}, \mathrm{e}}$ & $141.0 \pm 4.03^{\mathrm{d}, \mathrm{e}, \mathrm{f}}$ & $202.0 \pm 5.66^{b}$ \\
\hline B & $123.0 \pm 3.10^{\mathrm{e}, \mathrm{f}}$ & $143.0 \pm 4.30^{\mathrm{d}, \mathrm{e}, \mathrm{f}}$ & $250.5 \pm 7.80^{\mathrm{a}}$ \\
\hline \multirow[t]{2}{*}{ BV } & $97.7 \pm 2.90 \mathrm{~g}, \mathrm{~h}$ & $150.3 \pm 4.75^{\mathrm{c}, \mathrm{d}}$ & $236.2 \pm 8.20^{a}$ \\
\hline & \multicolumn{3}{|c|}{ B-glucosidase ( $\mu$ g p-nitrophenol/g.h) } \\
\hline CTR & $5.0 \pm 0.19 \mathrm{~g}$ & $32.5 \pm 0.67 \mathrm{e}, \mathrm{f}$ & $78.4 \pm 1.81^{\mathrm{c}}$ \\
\hline $\mathrm{V}$ & $15.7 \pm 0.51^{\mathrm{f}, \mathrm{g}}$ & $68.2 \pm 1.69^{\mathrm{c}, \mathrm{d}}$ & $108.3 \pm 2.94^{\mathrm{a}, \mathrm{b}}$ \\
\hline B & $24.9 \pm 0.46^{\mathrm{f}, \mathrm{g}}$ & $51.4 \pm 1.29^{\mathrm{d}, \mathrm{e}}$ & $86.3 \pm 1.89^{b, c}$ \\
\hline \multirow[t]{2}{*}{$\mathrm{BV}$} & $22.5 \pm 0.47^{\mathrm{f}, \mathrm{g}}$ & $51.3 \pm 0.95^{\mathrm{d}, \mathrm{e}}$ & $124.1 \pm 3.01^{\mathrm{a}}$ \\
\hline & \multicolumn{3}{|c|}{ Arylsulphatase ( $\mu \mathrm{g}$ p-nitrophenol/g.h) } \\
\hline CTR & $0.5 \pm 0.02^{f}$ & $4.9 \pm 0.12^{\mathrm{d}, \mathrm{e}}$ & $9.2 \pm 0.45^{b, c}$ \\
\hline $\mathrm{V}$ & $1.3 \pm 0.06^{\mathrm{f}}$ & $10.0 \pm 0.39^{a, b, c}$ & $12.3 \pm 0.57^{\mathrm{a}}$ \\
\hline B & $1.7 \pm 0.10^{f}$ & $7.3 \pm 0.34^{\mathrm{c}, \mathrm{d}}$ & $10.5 \pm 0.21^{\mathrm{a}, \mathrm{b}}$ \\
\hline \multirow[t]{2}{*}{$\mathrm{BV}$} & $2.4 \pm 0.09^{\mathrm{e}, \mathrm{f}}$ & $7.4 \pm 0.31^{\mathrm{c}, \mathrm{d}}$ & $11.0 \pm 0.27^{\mathrm{a}, \mathrm{b}}$ \\
\hline & \multicolumn{3}{|c|}{ Urease $\left(\mathrm{mg} \mathrm{NH}_{4}^{+}-\mathrm{N} / \mathrm{g} \cdot 2 \mathrm{~h}\right)$} \\
\hline CTR & $37.3 \pm 1.40^{\mathrm{e}}$ & $112.7 \pm 4.34 \mathrm{~d}, \mathrm{e}$ & $356.0 \pm 15.4^{\mathrm{c}}$ \\
\hline $\mathrm{V}$ & $30.3 \pm 1.30^{\mathrm{e}}$ & $158.4 \pm 6.68^{d}$ & $630.6 \pm 28.1^{\mathrm{a}}$ \\
\hline B & $79.3 \pm 2.20^{\mathrm{e}, \mathrm{d}}$ & $144.4 \pm 5.89^{d}$ & $467.7 \pm 22.2^{b}$ \\
\hline BV & $55.3 \pm 1.60^{\mathrm{e}}$ & $153.0 \pm 5.57^{\mathrm{d}}$ & $652.2 \pm 24.8^{a}$ \\
\hline
\end{tabular}

At T100, DH-ase activity did not differ significantly among fertiliser treatments within soil regions, but it was markedly higher in the Rz than the Bk soil: 2.2 times higher in $\mathrm{V}$, approximately 3-fold in CTR and B, and 3.5 times higher in BV. In the bulk soil, however, DH-ase activity was slightly higher in V $(0.75 \mu \mathrm{g} / \mathrm{g} / \mathrm{h} \mathrm{TTF})$ than in B and BV $(0.52$ and $0.46 \mu \mathrm{g} / \mathrm{g} / \mathrm{h}$ TTF, respectively), while in the Rz soil, it was quite similar in all treatments $(1.62 \mu \mathrm{g} / \mathrm{g} / \mathrm{h}$ TTF on average), suggesting that root exudates counterbalanced the negative effects of biochar. High soil DH-ase activity following $\mathrm{V}$ applications was reported by Arancon et al. [33], whereas the lower DH-ase found in BV compared with V can be explained by the presence of various toxic compounds in the biochar such as polycyclic aromatic hydrocarbons and volatile organic compounds [34]. Although losses of DH-ase in mixtures could be attributed to the decreasing effects of B on the enzyme activity, the values may also be underestimated because of the impact of biochar on assay constituents [16]. The lower level of DH-ase activity in the B treatments could also be explained by the findings of Swaine et al. [35], who reported that biochar amendments led to a significant reduction in concentrations of substrate and extractable product in soil DH-ase assays, thus limiting the identification of biochar effects on soil enzyme activity.

At T0, the alkaline phosphatase activity was significantly higher than in CTR in V and $\mathrm{B}$, but not in the combined application (BV), in which it even seemed to be depressed (Table 4). After tomato cultivation, AP-ase activity increased in both soil regions in the CTR and BV treatments, only in the Rz in V and B, and, for all treatments, values were significantly higher in Rz than in Bk at T100. Positive effects of biochar and vermiwash on AP-ase activity were reported by Lehmann et al. [26] and Uz et al. [29], but our results 
showed that the combined addition of the two materials did not enhance AP-ase activity in soil, which tended to be higher in the presence of biochar, especially in the rhizosphere (Table 4).

The activities of $\beta$-glucosidase and arylsulphatase were undoubtedly stimulated by the presence of $\mathrm{V}$ and $\mathrm{B}$, and for both, the differences to CTR became significant only after plant cultivation and were greatest with $\mathrm{V}$ in the Bk soil and with both $\mathrm{V}$ and $\mathrm{BV}$ in the $\mathrm{Rz}$ soil (Table 4). An increase in both GL and AS activities with the application of biochar to the soil were reported by Luo and $\mathrm{Gu}$ [36] and Lu et al. [37], whereas Günal et al. [38] found that $\beta$-glucosidase enzyme activity was found to vary greatly in response to the type of soil and biochar, and to the rates of application of biochar and fertilisers. In addition, Lim et al. [39] found that vermicompost increased $\beta$-glucosidase and other hydrolytic enzymes that play key roles in C, P, and S cycling.

The effect of $\mathrm{V}$ and $\mathrm{B}$ additions on urease activity increased considerably during tomato cultivation, but the differences to CTR became significant only in the rhizosphere soil, with approximately $82 \%$ higher UR activity in V and BV and $31 \%$ higher in B (Table 4). Among all tested enzyme activities, UR showed the greatest differences between soil regions, being approximately four times higher in the rhizosphere of tomato compared to the bulk soil, with a $\mathrm{BV}>\mathrm{V}>\mathrm{B}=\mathrm{C}$ trend. A surprisingly higher urease activity in the Rz compared to the $\mathrm{Bk}$ soil, associated with increasing variations in the fungal community during plant growth, was also observed after the shift to conservation tillage, and was imputed to changes in the soil nutrient status favoured by an increase in root exudates [40].

The alteration index three (AI3) is a data reduction process that involves the activities of three key enzymes: $\beta$-glucosidase, phosphatase, and urease, that are converted into scores reflecting the degree of positive or negative changes in the soil (alteration). The AI3 may be negative and positive and does not have target values [17]. Meyer et al. [41] reported that AI3 was correlated with soil organic matter content and yield performance. Analysing a set of amended and unamended soils, Puglisi et al. [17] observed that soils with more negative AI3 values had higher total organic carbon (TOC) content. Several studies confirmed the tendency of AI3 scores to become increasingly negative with increasing soil organic carbon content and soil quality $[42,43]$.

In this study, we used AI3 to compare altered (V, B, and BV) and unaltered (CTR) soils. In all treatments, the AI3 values became more negative from $\mathrm{T} 0$ to $\mathrm{T} 100$, thus highlighting an amelioration of soil quality during tomato cultivation (Table 5). In the bulk soil, AI3 did not differ significantly among fertiliser treatments at both T0 and T100, whereas the $\mathrm{Rz}$ values were more negative in the fertilised soils and especially in those amended with vermiwash.

Table 5. Alteration index three (AI3) of bulk and rhizosphere soils amended with different fertilisers at the start (T0) and end (T100) of tomato cultivation. CTR—control; V-vermiwash; B-biochar; BV-biochar together with vermiwash.

\begin{tabular}{cccc}
\hline & T0 & \multicolumn{2}{c}{ T100 } \\
\hline Fertiliser & Bulk & Bulk & Rhizosphere \\
\hline CTR & $-7.4 \pm 0.23^{\mathrm{a}}$ & $-12.9 \pm 0.45^{\mathrm{bc}}$ & $-21.6 \pm 0.95^{\mathrm{d}}$ \\
V & $-12.2 \pm 0.41^{\mathrm{a}, \mathrm{b}, \mathrm{c}}$ & $-13.0 \pm 0.54^{\mathrm{b}, \mathrm{c}}$ & $-32.8 \pm 1.11^{\mathrm{e}}$ \\
B & $-10.9 \pm 0.28^{\mathrm{a}, \mathrm{b}, \mathrm{c}}$ & $-14.5 \pm 0.63^{\mathrm{c}}$ & $-29.4 \pm 0.98^{\mathrm{d}}$ \\
BV & $-8.2 \pm 0.24^{\mathrm{a}, \mathrm{b}}$ & $-15.6 \pm 0.65^{\mathrm{c}}$ & $-34.0 \pm 1.14^{\mathrm{f}}$ \\
\hline
\end{tabular}

Values are means \pm SE; $n=5$. Different letters indicate significant differences among means ( $p<0.05$; Tukey's test).

These patterns demonstrate: (i) that root exudates play a key role in supporting soil biota, and (ii) that the application of appropriate amounts of $\mathrm{V}$ and $\mathrm{B}$ is helpful for the microorganisms of soil, leading to a higher biological quality of soil in the root environment. Moreover, the more negative AI3 recorded in BV at T100, both in the Bk and Rz soil, highlights that biochar is able to absorb and retain the organic molecules and the humic acids present in vermiwash, thus reducing both carbon and nitrate losses [31]. 


\title{
4. Conclusions
}

Both biochar and vermiwash provide the soil with organic matter and increase the microbial biomass, thus demonstrating to be useful to increase the native soil fertility. Soil enzymatic activities were stimulated by the presence of the two materials and increased after tomato cultivation, with slight synergies between biochar and vermiwash. The ranking among fertiliser treatments was similar in the two soil regions, but all enzyme activities turned out to be higher in the rhizosphere, revealing the contribution of root exudates to soil C metabolism.

The combined application of biochar and vermiwash could be a strategic and environmentally friendly instrument for preserving soil quality and reducing $\mathrm{C}$ losses in sustainable agriculture.

Further investigations should address the behaviour of biochar and vermiwash in the medium-long term, and in nutrient-poor soils.

\begin{abstract}
Author Contributions: All authors contributed to planning the experiment, and to the elaboration of the data and the preparation of the manuscript. Specific focus: conceptualisation, R.C. and M.B.; methodology, R.C., M.B., and I.A.; investigation, M.B.; data curation, R.C. and M.B.; writing-original draft preparation, M.B.; writing-review and editing, I.A.; visualisation and supervision, R.C. All authors have read and agreed to the published version of the manuscript.
\end{abstract}

Funding: This research received no external funding.

Institutional Review Board Statement: Not applicable.

Informed Consent Statement: Not applicable.

Data Availability Statement: The raw data supporting the conclusions of this manuscript are made available by the authors to any qualified researcher who makes a request.

Acknowledgments: The authors acknowledge RESET s.r.l. (Renewable Energy Solutions Environmental Technology, Rieti, Italy) for having produced and provided the biochar.

Conflicts of Interest: The authors declare no conflict of interest.

\section{References}

1. Laird, D.A.; Fleming, P.; Davis, D.D.; Horton, R.; Wang, B.; Karlen, D.L. Impact of biochar amendments on the quality of a typical Midwestern agricultural soil. Geoderma 2010, 158, 443-449. [CrossRef]

2. Lehmann, J.; Joseph, S. Biochar for Environmental Management. Science, Technology and Implementation, 2nd ed.; Routledge: London, UK, 2015; p. 944.

3. Mierzwa-Hersztek, M.; Gondek, K.; Baran, A. Effect of poultry litter biochar on soil enzymatic activity, ecotoxicity and plant growth. Appl. Soil Ecol. 2016, 105, 144-150. [CrossRef]

4. Ameloot, N.; De Neve, S.; Jegajeevagan, K.; Yildiz, G.; Buchan, D.; Funkuin, Y.N.; Prins, W.; Bouckaert, L.; Sleutel, S. Short-term $\mathrm{CO}_{2}$ and $\mathrm{N}_{2} \mathrm{O}$ emissions and microbial properties of biochar amended sandy loam soils. Soil Biol. Biochem. 2013, 57, 401-410. [CrossRef]

5. Joseph, S.; van Zwieten, L.; Chia, C.; Kimber, S.; Munroe, P.; Lin, Y.; Marjo, C.; Hook, J.; Thomas, T.; Nielsen, S.; et al. Designing specific biochars to address soil constraints: A developing industry. In Biochar and Soil Biota; Ladygina, N., Rineau, F., Eds.; CRC Press: Boca Raton, FL, USA, 2013; pp. 165-201.

6. Cardelli, R.; Becagli, M.; Marchini, F.; Saviozzi, A. Effect of biochar, green compost, and vermicompost on the quality of a calcareous soil: A 1-year laboratory experiment. Soil Sci. 2017, 182, 248-255. [CrossRef]

7. Pramanik, P.; Ghosh, G.K.; Ghosal, P.K.; Banik, P. Changes in organic-C, N, P and K and enzyme activities in vermicompost of biodegradable organic wastes under liming and microbial inoculants. Bioresour. Technol. 2007, 98, 2485-2494. [CrossRef]

8. Tejada, M.; González, J.L. Application of two vermicomposts on a rice crop: Effects on soil biological properties and rice quality and yield. Agron. J. 2009, 101, 336-344. [CrossRef]

9. Gutiérrez-Miceli, F.A.; Llaven, M.A.O.; Nazar, P.M.; Sesma, B.R.; Álvarez-Solís, J.D.; Dendooven, L. Optimization of vermicompost and worm-bed leachate for the organic cultivation of radish. J. Plant Nutr. 2011, 34, 1642-1653. [CrossRef]

10. Shivsubramanian, K.; Ganeshkumar, M. Influence of vermiwash on biological productivity of Marigold. Madras Agric. J. 2004, 91, 221-225.

11. Cissé, D.; Cornelis, J.T.; Traoré, M.; Saba, F.; Coulibaly, K.; Lefebvre, D.; Colinet, G.; Nacro, H.B. Co-composted biochar to decrease fertilization rates in cotton-maize rotation in Burkina Faso. Agron. J. 2021, 113, 5516-5526. [CrossRef]

12. Colombo, C.; Miano, T. Metodi di Analisi Chimica del Suolo; Società Italiana della Scienza del Suolo (SISS): Bari, Italy, 2015. 
13. Olivares, F.L.; Aguiar, N.O.; Rosa, R.C.C.; Canellas, L.P. Substrate biofortification in combination with foliar sprays of plant growth promoting bacteria and humic substances boosts production of organic tomatoes. Sci. Hortic. 2015, 183, 100-108. [CrossRef]

14. Barillot, C.D.C.; Sarde, C.O.; Bert, V.; Tarnaud, E.; Cochet, N. A standardized method for the sampling of rhizosphere and rhizoplan soil bacteria associated to a herbaceous root system. Ann. Microbiol. 2013, 63, 471-476. [CrossRef]

15. Vance, E.D.; Brookes, C.; Jenkinson, D.S. An extraction method for measuring soil microbial biomass carbon. Soil Biol. Biochem. 1987, 19, 403-707. [CrossRef]

16. Cardelli, R.; Becagli, M.; Marchini, F.; Saviozzi, A. Biochar impact on the estimation of the colorimetric-based enzymatic assays of soil. Soil Use Manag. 2019, 35, 478-481. [CrossRef]

17. Puglisi, E.; Del Re, A.A.M.; Rao, M.A.; Gianfreda, L. Development and validation of numerical indexes integrating enzyme activities of soils. Soil Biol. Biochem. 2006, 38, 1673-1681. [CrossRef]

18. Awad, Y.M.; Blagodatskaya, E.; Ok, Y.S.; Kuzyakov, Y. Effects of polyacrylamide, biopolymer, and biochar on decomposition of soil organic matter and plant residues as determined by 14C and enzyme activities. Eur. J. Soil Biol. 2012, 48, 1-10. [CrossRef]

19. Lei, O.; Zhang, R. Effects of biochars derived from different feedstocks and pyrolysis temperatures on soil physical and hydraulic properties. J. Soils Sediments 2013, 13, 1561-1572. [CrossRef]

20. Zimmerman, A.R.; Gao, B.; Ahn, M.Y. Positive and negative carbon mineralization priming effects among a variety of biocharamended soils. Soil Biol. Biochem. 2011, 43, 1169-1179. [CrossRef]

21. Angst, G.; Messinger, J.; Greiner, M.; Häusler, W.; Hertel, D.; Kirfel, K.; Kögel-Knabner, I.; Leuschner, C.; Rethemeyer, J.; Mueller, C.W. Soil organic carbon stocks in topsoil and subsoil controlled by parent material, carbon input in the rhizosphere, and microbial-derived compounds. Soil Biol. Biochem. 2018, 122, 19-30. [CrossRef]

22. Schulz, H.; Glaser, B. Effects of biochar compared to organic and inorganic fertilizers on soil quality and plant growth in a greenhouse experiment. J. Plant Nutr. Soil Sci. 2012, 175, 410-422. [CrossRef]

23. Pascual, J.A.; García, C.; Hernandez, T.; Ayuso, M. Changes in the microbial activity of an arid soil amended with urban organic wastes. Biol. Fertil. Soils 1997, 24, 429-434. [CrossRef]

24. Hailegnaw, N.S.; Mercl, F.; Pračke, K.; Száková, J.; Tlustoš, P. High temperature-produced biochar can be efficient in nitrate loss prevention and carbon sequestration. Geoderma 2019, 338, 48-55. [CrossRef]

25. Mukherjee, A.; Zimmerman, A.R. Organic carbon and nutrient release from a range of laboratory-produced biochars and biochar-soil mixtures. Geoderma 2013, 193, 122-130. [CrossRef]

26. Lehmann, J.; Rillig, M.C.; Thies, J.; Masiello, C.A.; Hockaday, W.C.; Crowley, D. Biochar effects on soil biota-A review. Soil Biol. Biochem. 2011, 43, 1812-1836. [CrossRef]

27. Zhou, H.; Zhang, D.; Wang, P.; Liu, X.; Cheng, K.; Li, L.; Zheng, J.; Zhang, X.; Zheng, J.; Crowley, D.; et al. Changes in microbial biomass and the metabolic quotient with biochar addition to agricultural soils: A Meta-analysis. Agric. Ecosyst. Environ. 2017, 239, 80-89. [CrossRef]

28. Aira, M.; Domínguez, J. Optimizing vermicomposting of animal wastes: Effects of rate of manure application on carbon loss and microbial stabilization. J. Environ. Manag. 2008, 88, 1525-1529. [CrossRef] [PubMed]

29. Uz, I.; Sonmez, S.; Tavali, I.E.; Çitak, S.; Uras, D.S.; Citak, S. Effect of vermicompost on chemical and biological properties of an alkaline soil with high lime content during celery (Apium graveolens L. var. dulce Mill.) production. Not. Bot. Horti Agrobot. 2016, 44, 280-290. [CrossRef]

30. Liang, C.; Cheng, G.; Wixon, D.L.; Balser, T.C. An Absorbing Markov Chain approach to understanding the microbial role in soil carbon stabilization. Biogeochemistry 2011, 106, 303-309. [CrossRef]

31. Becagli, M.; Guglielminetti, L.; Cardelli, R. Effects of combined biochar and vermicompost solution on leachate characterization and nitrogen balance from a greenhouse tomato (Solanum lycopersicum) cultivation soil. Commun. Soil Sci. Plant Anal. 2021, 52, 1879-1893. [CrossRef]

32. Gopal, M.; Gupta, A.; Thomas, G. Vermicompost and vermiwash add beneficial micro flora that enhance soil quality and sustain crop growth. Int. J. Innov. Hortic. 2012, 1, 93-100.

33. Arancon, N.Q.; Edwards, C.A.; Lee, S.; Byrne, R. Effects of humic acids from vermicomposts on plant growth. Eur. J. Soil Biol. 2006, 42, S65-S69. [CrossRef]

34. Dutta, T.; Kwon, E.; Bhattacharya, S.S.; Jeon, B.H.; Deep, A.; Uchimiya, M.; Kim, K.H. Polycyclic aromatic hydrocarbons and volatile organic compounds in biochar and biochar-amended soil: A review. GCB Bioenergy 2017, 9, 990-1004. [CrossRef]

35. Swaine, M.; Obrike, R.; Clark, J.M.; Shaw, L.J. Biochar alteration of the sorption of substrates and products in soil enzyme assays. Appl. Environ. Soil Sci. 2013, 2013, 968682. [CrossRef]

36. Luo, L.; Gu, J.D. Alteration of extracellular enzyme activity and microbial abundance by biochar addition: Implication for carbon sequestration in subtropical mangrove sediment. J. Environ. Manag. 2016, 182, 29-36. [CrossRef] [PubMed]

37. Lu, H.; Bian, R.; Xia, X.; Cheng, K.; Liu, X.; Liu, Y.; Wang, P.; Li, Z.; Zheng, J.; Zhang, X.; et al. Legacy of soil health improvement with carbon increase following one time amendment of biochar in a paddy soi-A rice farm trial. Geoderma 2020, $376,114567$. [CrossRef]

38. Günal, E.; Erdem, H.; Demirbaş, A. Effects of three biochar types on activity of $\beta$-glucosidase enzyme in two agricultural soils of different textures. Arch. Agron. Soil Sci. 2018, 64, 1963-1974. [CrossRef]

39. Lim, S.L.; Wu, T.Y.; Lim, P.N.; Shak, K.P.Y. The use of vermicompost in organic farming: Overview, effects on soil and economics. J. Sci. Food Agric. 2015, 95, 1143-1156. [CrossRef] 
40. Wang, P.; Marsh, E.L.; Ainsworth, E.A.; Leakey, A.D.B.; Sheflin, A.M.; Schachtman, D.P. Shifts in microbial communities in soil, rhizosphere and roots of two major crop systems under elevated $\mathrm{CO}_{2}$ and $\mathrm{O}_{3}$. Sci. Rep. 2017, 7, 15019. [CrossRef]

41. Meyer, A.H.; Wooldridge, J.; Dames, J.F. Relationship between soil alteration index three (AI3), soil organic matter and tree performance in a Cripps Pink/M7 apple orchard. S. Afr. J. Plant Soil 2014, 31, 173-175. [CrossRef]

42. Ghosh, A.; Singh, A.B.; Kumar, R.V.; Manna, M.C.; Bhattacharyya, R.; Rahman, M.M.; Sharma, P.; Rajput, P.S.; Misra, S. Soil enzymes and microbial elemental stoichiometry as bio-indicators of soil quality in diverse cropping systems and nutrient management practices of Indian Vertisols. Appl. Soil Ecol. 2020, 145, 103304. [CrossRef]

43. Van Huyssteen, I.; Mulidzi, A.R.; Meyer, A.H.; Wooldridge, J. Alteration Index Three facilitates interpretation of $\beta$-glucosidase, acid-phosphatase and urease activities in soils irrigated with diluted winery wastewater. S. Afr. J. Enol. Vitic. 2020, 41, 238-244. [CrossRef] 